\title{
Phytoprotection
}

\section{Efficacy, persistence, ground deposition, and human exposure of polymer-encapsulated lindane and chlorpyrifos used for control of the southern pine beetle}

\author{
C.W. Berisford, M.J. Dalusky, P.B. Bush, J.W. Taylor Jr. et Y.C. Berisford
}

Volume 72, numéro 1, 1991

URI : https://id.erudit.org/iderudit/705998ar

DOI : https://doi.org/10.7202/705998ar

Aller au sommaire du numéro

Éditeur(s)

Société de protection des plantes du Québec (SPPQ)l

ISSN

0031-9511 (imprimé)

1710-1603 (numérique)

Découvrir la revue

Citer cet article

Berisford, C., Dalusky, M., Bush, P., Taylor Jr., J. \& Berisford, Y. (1991). Efficacy, persistence, ground deposition, and human exposure of polymer-encapsulated lindane and chlorpyrifos used for control of the southern pine beetle.

Phytoprotection, 72(1), 15-20. https://doi.org/10.7202/705998ar
Résumé de l'article

Des applications de lindane et de chlorpyrifos ont été étudiées pour déterminer si l'encapsulation dans un polymère augmente la répression du dendroctone méridional du pin (Dendroctonusfrontalis), diminue l'étendue des retombées, augmente la durée d'adhésion à l'écorce ou réduit les contacts humains, en comparaison avec des applications de concentrés émulsifiés.L'encapsulation n'augmente pas l'efficacité et ne réduit pas les retombées des insecticides par rapport aux applications émulsifiées normales. L'encapsulation du chlorpyrifos augmente la persistance résiduelle mais n'affecte pas la persistance du lindane. Le risque de contact humain avec l'écorce encore humidifiée par le chlorpyrifos encapsulé est 2,2 fois plus élevé tandis que le risque de contact du lindane n'est pas influencé par l'encapsulation. Cependant, une fois l'insecticide séché, les applications encapsulées réduisent le risque de contact humain de $90 \%$ pour le lindane et de $83 \%$ pour le chlorpyrifos. 


\title{
Efficacy, persistence, ground deposition, and human exposure of polymer- encapsulated lindane and chlorpyrifos used for control of the southern pine beetle
}

\author{
C. Wayne Berisford, Mark J. Dalusky \\ Department of Entomology, University of Georgia, \\ Athens, Georgia 30602, U.S.A.
}

Parshall B. Bush

Cooperative Extension Service, Agricultural Services Research Laboratory,

University of Georgia, Athens, Georgia 30602, U.S.A.

John W. Taylor Jr.

USDA Forest Service, Forest Pest Management, Atlanta, Georgia 30367, U.S.A.

\author{
Yvette C. Berisford \\ Cooperative Extension Service, Agricultural Services Research Laboratory, \\ University of Georgia, Athens, Georgia 30602, U.S.A.
}

(Received 1990-04-04; accepted 1991-03-05)

\begin{abstract}
Formulations of lindane and chlorpyrifos were evaluated to determine if polymer encapsulation extended the duration of southern pine beetle (Dendroctonu frontalis) control, reduced ground deposition, increased persistence on bark or reduced potential human exposure relative to emulsifiable concentrate formulations. Encapsulation did not extend efficacy or reduce ground deposition of either insecticide when compared with the standard emulsifiable formulations. Encapsulation extended residue persistence of chlorpyrifos on bark, but not of lindane. The potential risk of human exposure to bark which was still wet with chlorpyrifos was increased 2.2 times by encapsulation, whereas, similar exposure to lindane was unaffected by encapsulation. After the insecticides had dried on the bark, the encapsulated formulations reduced risk to lindane by approximately $90 \%$ and by $83 \%$ for chlorpyrifos.
\end{abstract}

Berisford, C. W., M. J. Dalusky, P. B. Bush, J. W. Taylor Jr., and Y. C. Berisford. 1991. Efficacy, persistence, ground deposition, and human exposure of polymer-encapsulated lindane and chlorpyrifos used for control of the southern pine beetle. PHYTOPROTECTION 72: 15-20.

Des applications de lindane et de chlorpyrifos ont été étudiées pour déterminer si l'encapsulation dans un polymère augmente la répression du dendroctone méridional du pin (Dendroctonus frontalis), diminue l'étendue des retombées, augmente la durée d'adhésion à l'écorce ou réduit les contacts humains, en comparaison avec des applications de concentrés émulsifiés. L'encapsulation n'augmente pas l'efficacité et ne réduit pas les retombées des insecticides par rapport aux applications émulsifiées normales. L'encapsulation du chlorpyrifos augmente la persistance résiduelle mais n'affecte pas la persistance du lindane. Le risque de contact humain avec l'écorce encore humidifiée par le chlorpyrifos encapsulé est 2,2 fois plus élevé tandis que le risque de contact du lindane n'est pas influencé par l'encapsulation. Cependant, une fois l'insecticide séché, les applications encapsulées réduisent le risque de contact humain de $90 \%$ pour le lindane et de $83 \%$ pour le chlorpyrifos.

\section{Introduction}

Lindane and chlorpyrifos are used for remedial and preventive control of bark beetles (Dendroctonus spp.) in high value pines (Pinus spp.) (Berisford and Brady 1976; Berisford et al. 1981 a, 1981 b; Billings 1980; Brady et al. 1980; Smith 1967). These pines are an important asset in residential and private landscaping programs and in public recreational areas such as parks and campgrounds. One applica- tion of lindane can prevent successful attack by the southern pine beetle (Dendroctonus frontalis Zimmermann) for up to one year, but at least two annual applications of chlorpyrifos are needed for comparable protection (Berisford and Brady 1976; Berisford et al. 1981a, 1981c; Brady et al. 1980). Because humans may contact sprayed bark, there is a potential risk of dermal absorption of the insecticides. This risk could be reduced by using a formulation which strongly binds to the bark so that the insecticide cannot easily be rubbed off or by decreasing the number of insecticide applications by using a formula- 
tion which extends the protection period of the insecticide.

One approach to extending the effective life of insecticides is to encase them in a polymer. In a laboratory bioassay study, a polymer-encapsulated formulation of chlorpyrifos extended its efficacy (against cockroaches, Blatella americana L.) up to 12 times that of the unencapsulated formulation (C. M. Himel, University of Georgia, unpublished data). In the field, encapsulated formulations may extend the effective life of insecticides by protecting them from weathering and wash-off. The encapsulated formulations may also reduce nontarget exposure since the toxic materials are encased in the polymer and, therefore, are not directly exposed to humans or other animals which may contact sprayed surfaces.

The objective of this study was to compare the encapsulated formulation (ENC) of lindane and chlorpyrifos with the standard emulsifiable concentrate formulation (EC) to determine if encapsulation can: 1) prolong or enhance the efficacy of lindane and chlorpyrifos against the southern pine beetle; 2 ) reduce the potential deposition of pesticide on the ground during application; 3 ) increase residue persistence on bark; and 4) reduce human exposure from incidental contact with insecticides on bark.

\section{Material and methods}

Insecticides used in this study included lindane $(1,2,3,4,5,6$-hexachlorocyclohexane, at least $99 \%$ gamma isomer) and chlorpyrifos (0,0-diethyl, 0-[3, 5, 6-trichloro-2-pyridyl] phosphorothioate, Dursban ${ }^{\mathrm{R}}$ formulation). Insecticides were applied either as an emulsifiable concentrate formulation (EC) or as a polymer-encapsulated formulation (ENC). The polymer encapsulated formulations were supplied by Spray Control Systems, Inc., Watkinsville, GA, USA. The EC spray solutions were made from either Lindane $20 \mathrm{EC}$ (20\% lindane) or Dursban 4E (42.8\% chlorpyrifos). Lindane and chlorpyrifos were applied at $0.5 \%$ active ingredient and $2.0 \%$ active ingredient, respectively, regardless of the formulation used. All applications were made with a high pressure hydraulic sprayer (1373$2746 \mathrm{kPa}$ ). Tree boles were sprayed about half way into the live crown.
Efficacy study. Loblolly pines (Pinus taeda L.) at the University of Georgia School of Forest Resources Experimental Forest, Whitehall, Georgia, were sprayed with the ENC or EC formulations between November 1985 and April 1986. Thirty trees were treated with each formulation to allow up to two years for evaluation if necessary. After the insecticides had dried on the bark and at threemonth intervals thereafter, three trees per treatment were felled, and two 1.5 -m long bolts (sections) were removed from the central portion of each tree trunk for a total of 6 replicates per treatment. These bolts were then exposed to southern pine beetle attack within nearby infestations for two weeks by a "hanging bolt" assay (Berisford et al. 1980). Each bolt was baited with the southern pine beetle aggregation pheromone, frontalure, and fitted with a Stickem Special ${ }^{\circledR}$-coated metal screen $(50 \mathrm{~cm} \mathrm{X} 20 \mathrm{~cm})$ to monitor beetle visitations. After two weeks, the numbers of southern pine beetles trapped were counted. The numbers of attacks identified by boring holes and the total length of egg galleries were recorded in a $1000 \mathrm{~cm}^{2}$ area on each bolt opposite the Stickem screen trap. 'Treatment efficacy was determined by comparing the mean number of attacks and the mean egg gallery length among treated and control bolts.

\section{Persistence and ground deposition stud-} ies. These studies were conducted on shortleaf pine (Pinus echinata Miller) in the U.S. Forest Service Beech Creek Seed Orchard, Murphy, North Carolina from July 1985 through January 1987. Bark samples were taken at breast height from three different trees per treatment at 2-3 $\mathrm{h}$ after spraying and thereafter at three-month intervals for 18 months. Samples of the outer $1.27 \mathrm{~cm}$ of bark (ca. $100 \mathrm{~g}$ ) were collected and processed for pesticide residue analysis as described in Bush etal.(1987).

Insecticide deposition on the ground was measured on 9-cm diameter filter discs placed beneath each of 10 trees per treatment. The area circumscribed by a $3.65-\mathrm{m}$ radius beneath each tree was sectored into four quadrants and two filter discs were randomly placed in each quadrant. Trees were $4.5 \mathrm{~m}$ apart in rows which were $9.12 \mathrm{~m}$ apart. Samples were processed as described above for residues on bark. 
Human exposure study. Potential human exposure by contact with sprayed trees was simulated by firmly rubbing the chest area of cotton T-shirts for $30 \mathrm{~s}$ over a $0.37 \mathrm{~m}^{2}$ area of treated bark. For residue analysis, a $20 \mathrm{~cm} \mathrm{X}$ $20 \mathrm{~cm}$ patch from each T-shirt was extracted in toluene (lindane) or ethyl acetate (chlorpyrifos) and analyzed by gas chromatography (Bush et al. 1987). The test was conducted while bark was still wet with the insecticides and then one day later after the insecticides had dried on the bark. Each test was replicated 10 times. This study was conducted on loblolly pines at the University of Georgia School of Forest Resources Experimental Forest, Whitehall, Georgia, in December 1989.

Data analysis. The effect of formulation on pesticide efficacy, persistence, deposition on the ground, and human exposure was assessed by subjecting the data to an analysis of variance for unbalanced data. When the treatment effect was significant $(P \leq 0.05)$, means were compared and separated by Duncan's multiple range test. Statistical analyses were performed using programs from the SAS Institute, Inc. (SAS 1988).

\section{Results and discussion}

Efficacy. Encapsulation did not increase or extend the efficacy of lindane or chlorpyrifos (Fig. 1), even though chlorpyrifos residues were higher (Fig. 2). Although lindane dissipated from bark more rapidly than chlorpyrifos, it was more effective than chlorpyrifos, protecting trees from successful southern pine beetle attack (i.e., gallery construction) for at least 12 months. On lindane-treated trees, successful beetle attack occurred between 12 and 21 months after application (Fig. 1C). During this interval, bark residues fell below $30 \mathrm{ppm}$ (Fig. 2A). These results are similar to previous reports of successful pine beetle attacks when bark residues fell to $37 \mathrm{ppm}$ (Brady et al. 1980) or attacks of Ips spp. bark beetles when residues fell below $30 \mathrm{ppm}$ (Berisford and Brady 1976). However, even at 21 months, both formulations of lindane provided a substantial level of protection relative to control trees. Whether this represents a biologically significant level of efficacy is unknown, since beetles had established a few egg galleries at the time of evaluation. The exact number of southern pine beetles re- quired to kill trees has not been established. An 18-month evaluation could not be made because beetle populations were unavailable. However, lindane formulations should have been effective in preventing attack based on the 21 -month data (ENC - $78 \%$ reduction in attacks and $90 \%$ reduction in total egg gallery length; EC - 90\% reduction in attacks and $97 \%$ reduction in total egg gallery length).

Encapsulated chlorpyrifos afforded some protection initially but three months after application, mean gallery length was not significantly different between control and treated trees.

Persistence on bark. Lindane residues on bark sprayed with either formulation were not significantly different (Fig. 2A). In contrast, chlorpyrifos residues from the encapsulated formulation were 2.5 to 4.5 times higher than residues from the EC formulation on each sampling date ( 3 to 18 months after application, Fig. 2B). At the end of the 18-month sampling period, $39.2 \%$ of the initial chlorpyrifos residues remained on the bark of ENCsprayed trees whereas, only $12.9 \%$ remained on the bark treated with the EC formulation.

Encapsulation increased the chlorpyrifos residue level on bark and decreased the degradation rate. The residue level from treatments sampled 0 to 18 months after application was high enough to prevent southern pine beetle attack (Fig. 2B). However, the amount of active ingredient actually available to the beetles was apparently unaffected by formulation and may have been "tied up" by the polymer. The net result was higher and more persistent bark residues but no increase in bark beetle control. It may be possible to adjust the polymer or similar systems to maintain the higher residues and still release enough toxicant to increase efficacy.

Deposition of insecticides on the ground. Encapsulation did not significantly affect the deposition of chlorpyrifos or lindane on the ground. The mean deposition $( \pm$ S.D. $)$ of each formulation was as follows: chlorpyrifos EC $-1.837 \pm 2.506 \mathrm{~kg} / \mathrm{ha}, \mathrm{ENC}-1.167 \pm 1.350$ $\mathrm{kg} / \mathrm{ha}$; lindane EC $-0.026 \pm 0.031 \mathrm{~kg} / \mathrm{ha}, \mathrm{ENC}$ $-0.047 \pm 0.034 \mathrm{~kg} / \mathrm{ha}$.

Human exposure. Chlorpyrifos residues on T-shirts rubbed on the bark that was still wet with the encapsulated formulation were 
2.2 times greater than that from the $\mathrm{EC}$ formulation, but there was no significant difference in lindane residues between the different formulations (Fig. 3A). The higher residue lev- els on the T-shirts rubbed on bark wet with encapsulated chlorpyrifos may be at least partly due to differential drying times between the ENC and EC formulations. The

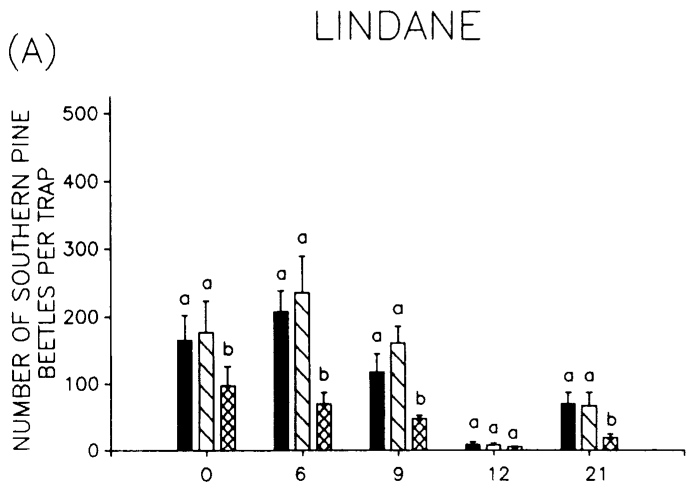

\section{CHLORPYRIFOS}

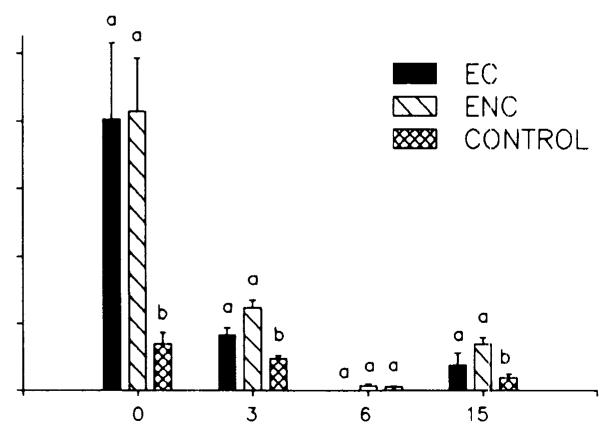

(B)
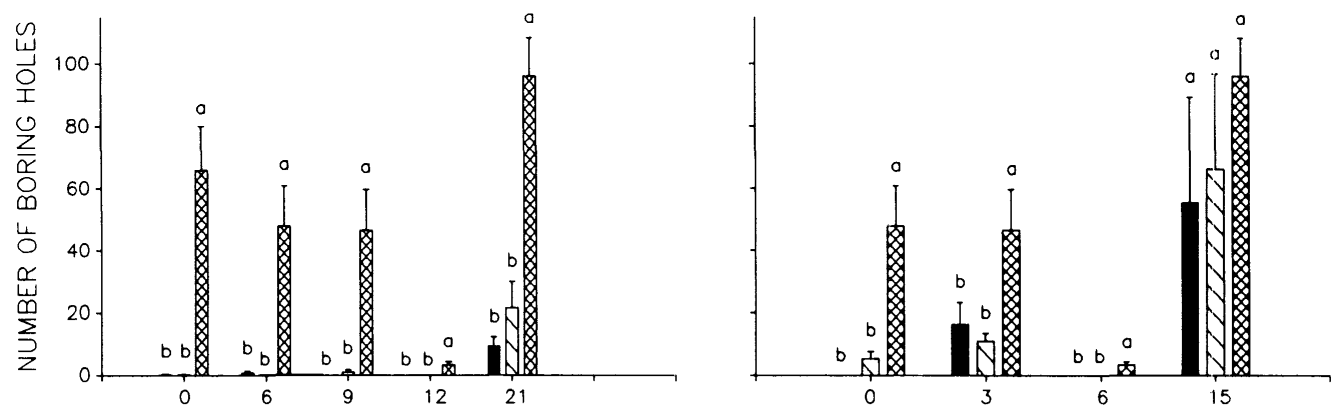

(C)
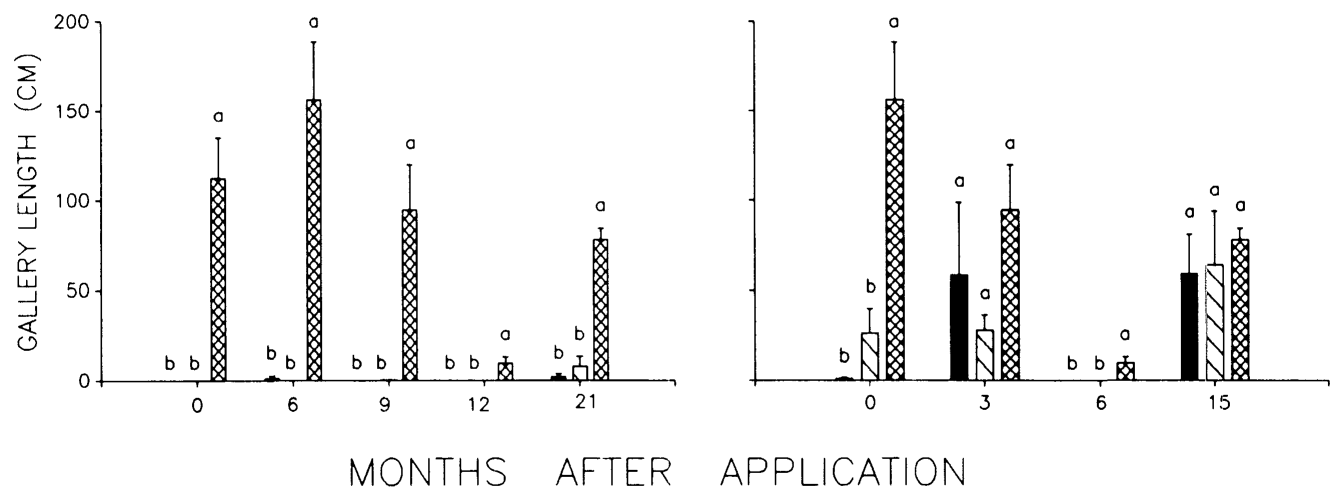

APPLICATION

Figure 1. Efficacy of lindane and chlorpyrifos formulations in controlling the southern pine beetle: (A) number of beetles on traps placed on treated tree bolts, $(B)$ number of boring holes in bark, and $(C)$ total length of southern pine beetle egg galleries. The same letters over graph bars indicate no significant difference $(P>$ 0.05 ) between formulations at each month following application. EC: emulsifiable formulation; ENC: encapsulated formulation. 
(A)

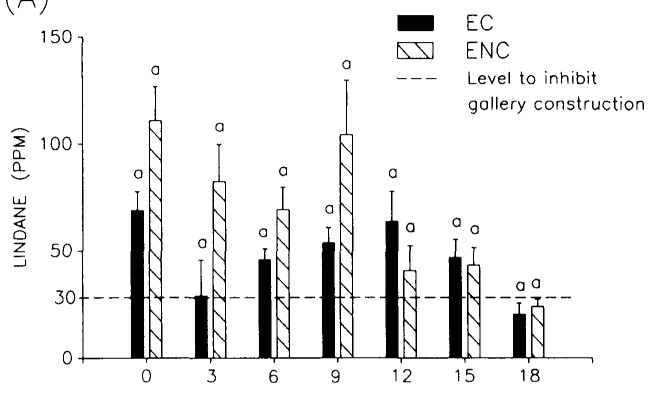

(B)

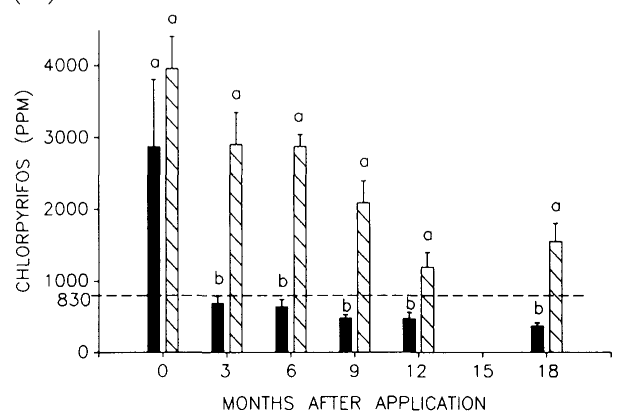

Figure 2. Residue levels of lindane (A) and chlorpyrifos (B) on bark of standing shortleaf pine. Residue levels of approximately $30 \mathrm{ppm}$ lindane and $830 \mathrm{ppm}$ chlorpyrifos are needed to control southern pine beetles. The same letters over graph bars indicate no significant difference $(P>0.05)$ between formulations at each month following application. EC: emulsifiable formulation; ENC: encapsulated formulation; - - -: approximate level to inhibit gallery construction.

encapsulated formulation may have taken longer to soak into or to bind with the bark. Once the insecticides had dried, residues on the T-shirts from trees treated with the encapsulated formulations were approximately $10 \%$ and $17 \%$ of that from the EC formulations for lindane and chlorpyrifos, respectively (Fig. 3B). Therefore, once dried on the bark, the encapsulated formulations significantly reduced human exposure risk relative to the EC formulations.

\section{Conclusion}

The encapsulated insecticides greatly reduced human exposure to both lindane and chlorpyrifos. These formulations might there-

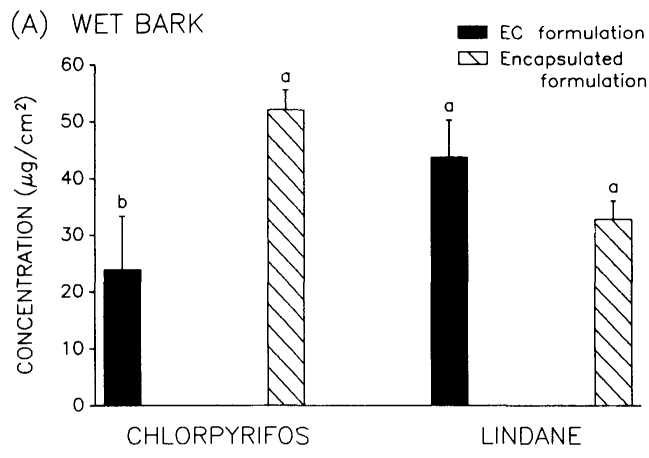

(B) DRY BARK

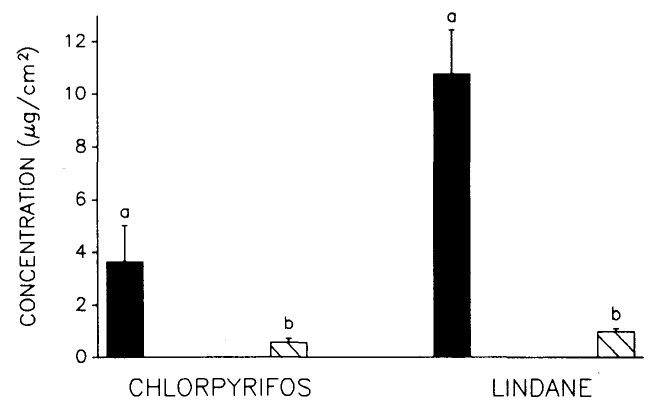

Figure 3. Simulated worker exposure to contact with lindane and chlorpyrifos formulations on (A) wet bark or (B) dry bark. The same letters over graph bars indicate no significant difference $(P>0.05)$ between formulations of the same insecticide. (Human exposure is expressed as the concentration of insecticide per $\mathrm{cm}^{2}$ cotton T-shirt rubbed on wet or dry bark.) EC: emulsifiable formulation; ENC: encapsulated formulation.

fore be desirable for protection of trees in high-use areas such as parks and campgrounds. Although residues of encapsulated chlorpyrifos persisted at levels which should have extended protection from bark beetle attack relative to the $\mathrm{EC}$ formulation, actual efficacy was not significantly different between formulations. The toxicant was apparently tiedup within the polymer and was not contacted by attacking beetles. Encapsulation was therefore advantageous in reducing human exposure, but did not improve bark beetle control, nor did it reduce the amount of insecticide deposited on the ground during application. Perhaps the encapsulated formulations could be refined to release more toxicant to the beetles without significantly decreasing bark residues. 
This research was supported by the United States Department of Agriculture - National Agricultural Pesticide Impact Assessment Program, the USDAForest Service (Forest Pest Management, Southern Region), and the Georgia Agricultural Experiment Stations. The authors thank Dr. Norman Herz, Center for Archaeological Studies, University of Georgia, for providing the French translation of the abstract.

Berisford, C.W., and U.E. Brady. 1976. Duration of protection of loblolly pines from $I p s$ bark beetles by lindane. J. Econ. Entomol. 69: 357-358.

Berisford, C.W., U.E. Brady, R.F. Mizell III, J.H. Lashomb, G.E. Fitzpatrick, I.R. Ragenovich, and F.L. Hastings. 1980. A technique for field testing insecticides for long-term prevention of bark beetle attack. J. Econ. Entomol. 73: 694-697.

Berisford, C.W., U.E. Brady, G.E. Fitzpatrick, C.K. Franklin, F.L.Hastings, A.S.Jones, J.H.Lashomb, R.F. Mizell III, W.W. Neel, and I.R. Ragenovich. 1981a. Efficacy studies: prevention. Pages $3-8$ in F.L. Hastings and J.E. Coster (eds.), Field and laboratory evaluations of insecticides for southern pine beetle control. USDA Forest Service, Gen. Tech. Rep. SE-21, Southeast. Forest Exp. Stn., Asheville, N.C.
Berisford, C.W., U.E. Brady, G.E. Fitzpatrick, J.H. Lashomb, R.F. Mizell III, W.W. Neel, and I.R. Ragenovich. 1981b. Efficacy studies: remedial. Pages 9-12 in F.L. Hastings and J.E. Coster (eds.), Field and laboratory evaluations of insecticides for southern pine beetle control. USDA Forest Service, Gen. Tech. Rep. SE-21, Southeast. Forest Exp. Stn., Asheville, N.C.

Berisford, C.W., U.E. Brady, and I.R. Ragenovich. 1981c. Residue studies. Pages 11-14 in F.L. Hastings and J.E. Coster (eds.), Field and laboratory evaluations of insecticides for southern pine beetle control. USDA Forest Service, Gen. Tech. Rep. SE-21, Southeast. Forest Exp. Stn., Asheville, N.C.

Billings, R.F. 1980. Direct control. Pages 179-192 in R.C. Thatcher, J.L. Searcy, J.E. Coster, and G.D. Hertel (eds.), The southern pine beetle. USDA Forest Service, Sci. Educ. Admin., Tech. Bull. No. 1631.

Brady, U.E., C.W. Berisford, T.L. Hall, and J.S. Hamilton. 1980. Efficacy and persistence of chlorpyrifos, chlorprifos-methyl, and lindane for preventive and remedial control of the southern pine beetle. $J$. Econ. Entomol. 73: 639-642.

Bush, P.B., J.W. Taylor, C.K. McMahon, and D.G. Neary. 1987. Residues of lindane and chlorpyrifos in firewood and woodsmoke. J. Entomol. Sci. 22: 131-139.

SAS 1988. SAS/STAT User's guide: Release 6.03 Edition. SAS Institute Inc., Cary, N.C. 1029 pp.

Smith, R.H. 1967. Lindane in diesel oil prevents western pine beetle attacks for at least one year. J. Econ. Entomol. 60: 1746-1747. 